\title{
ニューラルネットワークによる 動的システムの学習と制御
}

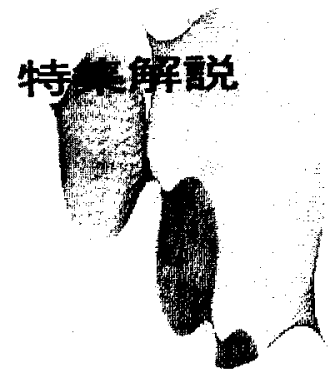

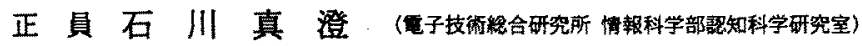

\section{1.はじめに}

コネクショニスムムは神経科学にヒントを得て, 各々 は単純な機能しかもたない多数のユニットをネットワ 一ク状に構成することにより，全体として複雑な機能 を有する人間の知覚・認知のモデルをねらおうとする ものである。この考充方に基づくコネクショニストも テル〈ニューラルネットワーク, PDPモデル, 並列 分散処理モデルなどとも呼ばれる。以下では，著者の 好みに従ってコネクショニストモデルと呼びたい) を, パターン認識を始めとする様々な分野に道用し上 うという動きが最近数多く見受けられる(1) (3)。

コネクシュニストモデルでは多くの場合, パターン の出現暊序には本贀的な意味がない。ところが制御な どのように, パターンの出現順序, 言い換えれば系列 が本質的な意味をもつものもある。このようないわ田 るダイナミクスをモデル上でいかに表現するかは，そ の学習や制御にとって重大な課題である。本稿では, 系列を报う目的・モデル形式について論じ，併せて興 味深い研究例を幾つか紹介したい。

\section{2. 系列を扱う目的}

ここではまず系列を扱う目的を整理し，この目的と モデル形式の関係について考察する(()。系列あるいは ダイナミクスを扱う目的として, 系列の学習, 生成, 認識，特徴抽出，制御などが考えられる。

学習とは, 与えられた（一般には複数個の）系列を 記檍することである。歴史的には心理学の中て人間の 系列記憶のためのモデルとして考えられた。記号系列 の場合には，同一の部分系列が複数ある場合その後に

Learning and Control of Dynamic Systems by Neural Networks. By Masumi lshikawa, Member (Cognitive Science Section, Information Science Division, Electrotechnical Laboratory).
何がくるかをきちんと判別して学習できるかどうかが 問題となる。

生成とは，系列の一部が与えられた場合，何らかの 基準に基づく内掩により系列全体を作り出すことてあ る。例えば，過剩な自由度を利用して系列を時間軸に 浻って滑らかにつなぐことはその一例である(6)。

㷵識とは，幾つかの系列のクラス夕化を学習してお き，新たに与えられた采列がどのクラスタに属するか を判別することてある。パターンの判別は本来コネク ショニストモデルに適した領域であるが, 系列である がゆえの困難が発生する(4)。

特徵抽出とは，系列からその統計的性質などの特徽 を抽出することである(5)。後述のようにこれもコネク ショニストモデルに適した課題と言えよう。

制御とは，動特性を有るる対象の出力がある目標系 列に近づくように入力系列を求めることである。人間 の筋肉の制御との関連で, 更にはロボットアームの制 御への応用の観点からも興味深い課題である(12)。

ここで学習と制御の関連について考えて見よう。学 習とは入力から出力への写像が再現できるようモデル を調整することであり，新しい入力が加わっても一般 化により，適切な出力を出すことが期待される。一般 に，この学習は多対一問題である。これに対して，学 習後に出力目標系列を与えてこれに対応する入力系列 を求める制御問題は，一般に一対多問題となり，本質 的な困難を含んている。従って，単に出力から入力八 の逆写像を別途学習させるのでは，一対多問题が無視 されることになる。

なお、ここでの系列は大別すると（離散的な）記号 の系列と連続的な値の系列とに分けられる。前者の例 としては，人間の系列記億のためのモデルがある。後 者の例としては，音声発声の調音結合モデルがある。 学習の特性がこの二者の閒てかなり異なるが，詳細は 
割要したい(4)。

\section{3. 系列を扱うコネクショニストモテル}

系列が报えるコネクショニストモデルを歴史的視点 から眺めて芫上う ${ }^{(6)}$ 。最初に思いつくのは連想ネット ワーク (associative chaining) であるが、これには 同じ要素群の異なる序列が扱光ない，コンテクスト効 果が入らないなどの問題点がある。

これに対し，Wickelgrenは要素の三つ組を制御要 素とする連想ネットワークを提案し，上記問題点を解 決しようとした。これは例えば, 系列 $A B C$ の中での 要素 $B$ の制御要素を $a B c$ で表し, 系列 $C B A$ 中での 要素 $B$ の制御要素を $c B a$ で表すというものである。 従って，必要となる制御要素数が大きくなる。長いコ ンテクスト効果を考虑しようとすると, 必要な制御要 素数は更に增大する。またタイプがなくトークンのみ なので言語的・音䫓的規則性への一般化が困難である。

Rumelhart らは, 行動をパラレルに生成するモデ ルを提案し，これにより種々のタイピングミスの説明 が可能になった ${ }^{(7)}$ 。しかし繰返し行動がうまく扱えな い，望ましくない並列性を制限できないなどの問題点 がある。これは, 行動の並列性と行動の時間的順序と いう二つの異なった事柄を一つの出力層の活性度にま とめて表現することに起因する。

Jordanは, システムの出力層抢よび状態層という 2 種類の層を取入れたコンテクストモデルによりこの 問題を解決している(6)。言い換光れは造次序列問題を 状態ベクトルの時間的変化, および状態の行動への変 換という二つの部分問題に分割している。これには, コンテクスト依存性を表現でき，明示的な制御を導入 する必要がないなどの利点がある。Jordanの提案は 単純な非階層的モデルであるが，宮田はこれを階層的 モデルに搪張した(8)。

一般にコンテクストモデルは, 出力層, 隠れ層; あ るいは入力層の過去の情報を指数減衰的に包含したも のを状態畨（あるいはコンテクスト層）で表現するも のである。例えば図1に示すジョルダンのネットワー クは, 出力層 $O_{t}$ の履歴として, 以下の活性度を有す る状態層を用いている。

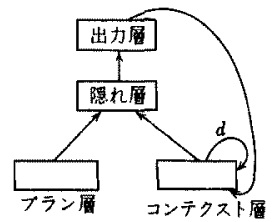

図 1 ジョルダンネットワーク
$O_{t-1}+d O_{t-2}+d^{2} O_{t-3}+d^{2} O_{t-4}+\cdots$

ただし, $d:$ 一時点前の状態の残存率

同図で系列によって異なるプラン層活性度パターン を用いることにより，複数系列が学習てきる。コンテ クストモデルは状態層・プラン屇と出力との関係を学 習するものである。時間的に近い状態層は類似してい るので時間軸上での一般化が行われ，パターンの時間 的変化を扱うことが可能になる。

別のタイプのモデルとして，バッファモデルがあ る。これは，図 2 に示すように最近の $n$ 個の要素を 入力系列とし，これと出力層との関係を学習するもの である。これにより，時間的認識をコネクショニスト モデルが得意な空間的認識に変換できる。この応用例 として, 例えば次の時点の入力パターンを出力と見な すことにより，生起確率・遷移確率などの系列の特暀 抽出が容易に行える(5)。なおバッファモデルの特殊な 場合として，系列全体をバッファに入れるモデルがあ り，これを全バッファモデルと呼ぶことにしよう。

ここで，コンテクストモデルとバッファモデルを比 較してみよう。コンテクストモデルは状態層に過去の 情報を指数減衰的にたたみ込んているため，この意味 付けがとりわけ連続值系列の場合あまり明確と蛙言い 難い。更に,このような固定的なネットワーク構造て いかなる系列をも扱えるかどうかは疑問である(4)。

他方，バッファモデルにも様々な問題点が指摘され ている(11)(14)。第 1 に，コンテクストに影響を与え得 る最も長い入力系列をバッファに入れておく必要があ るため，この長さを事前に知る必要がある。場合によ っては極めて長い系列を用意する必要が生ずる。第2 に，バッファ数が增えると多量の情報を同時に报わな ければならないため，多くの計算量を要する。第 3 に，パッファ数が增えるとリンク数も增えここれを学 習させるのに多くの訓練パターンが必要となる。第 4 に，時間軸方向の変化に対して不変でない。言い換え れば，ある時点でのバッファ $\left\{X_{1}, X_{2}, \cdots, X_{N}\right\}$ が次の 時点には $\left\{X_{2}, X_{3}, \cdots, X_{N+1}\right\}$ となり, 両者の関連性が わかり難くなる。

また全バッファモデルの場合には上記問題点に加え

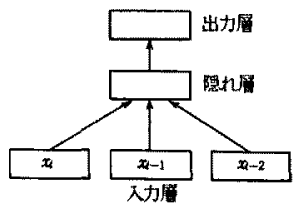

图 2 バッファモデル 
て, 第 5 にバッファ長が更に長くなる。第 6 に, 近い 時間関保のほうが遠い時間関係よりも影響が大きいは ずなのにこのような構造的制約を入れ難い。第 7 K, 時点ごとにコピーを用意し, 一時点での学習を一 般化して他の時点に伝搬する必要性が生ずる。

\section{4. 調音結合モデル}

Jordanは，例えば手足の連動・発声など一見逐次的 に見えるものも，詳細に見ると並列性を有していると いう人間の振舞のモデル化を行った。発声の際の調音 結合 (coarticulation) がその良い例であり，並列性 のためスムーズな発声が可能になっている。

例兑ば，freonというフランス語の単語を発声す る際，鼻音 $/ \mathrm{n} / *$ のため軟口蓋を開くが最初の母音 le/で既に開き始め，そのため母音が鼻母音化する。 同様にune sinistre structureという句の発声の際, /istrstry/では/y/の唇の丸めが最初の/s/から始 まり，また真ん中の $/ r /$ が近くの $/ \mathrm{i} /, / \mathrm{y} /$ などに影 響されて若干有声になる。これらの例からもわかるよ うに, 発声は逐次性と並列性の入り交じった複雑な制 御問題である。

Jordanは, 図 1 のコンテクストモテル構造を用い て上記調音結合のモデル化を行っている。ここで状態 唇には出力の履歴が蓄えられている。特徵量として, 有声・位置 - 共鳴音・菡擦音・鼻音・高さ ・後舌面・ 噚の丸めの8 種類が用いられている。各時点におい て,これら特徴量の出力目標を与えるのであるが, 音 声構造の知識に基づいて, ある特徵量は目標值を指 定し，ある特徵量は目標值を指定せず，いわゆる don't-care 条件とする。バックプロパゲーション学習 に招いても， don't-care 条件侅当する出カユニット からは誤差を逆伝般させない。

学習の過程で don't-care 条件に該当する出カユニ ットの值は時間的に近くの音素との間に並列的交互作 用が発生する。これにより調音結合が生成される。こ のモデルでは，ある音素列の発声がネットワークの重 みという形でインプリシットにしか表現されておら ず、ネットワークが動いて始めてその発声の時間的推 移が明示的に明らかになる。

伝統的モータプログラムアプローチ**で並列性や相 互作用を説明するには特別のメカニズムを用意しなけ ればならないのに対しここでのモデルでは状態とい う概念を導入することにより，内在する過剩自由度が 自然な形で並列性を生成している。過剩自由度が小さ

\footnotetext{
*：/109中は発音記甼てある。

**:本稿でモータとは筋肉のことを意味する。
}

電学論D, 109 巻 4 号, 平成元年
くなるにつれて並列性が減少し，逐次性はその極限の ケースに相当している。

しかし，各特徴量の物理的慣性などを明示的にモデ ル化しているわけではないので, 調音結合が生成され る説明としては面白いが，特徴量の時間的恣化の詳細 にそれほどの意味があるとは思えない。このために は，例えば後述のフォワードモデルのようなもつと複 雑なモデルが必要であろう。

\section{5. 行動計画モデル}

タイピングのような複雑なモータスキルの学習の際 には，個々の要素アクションが実行されるのではな く，モータ系列のチャンクが作られると言われてい る。コネクショニズムによるモータ制御ては，これま でエキスパートの振舞のモデル化に興味があったのに 対し, 宮田はモータスキルの学盟に際して初心者から エキスパートへの変遷が扱えるモデルを提案してい $\Xi^{(8)}$ 。

モデル構造として, ジョルダンのネットワークをニ 段に積み重ねたものを用いる。プランネットと呼ばれ る初段のネットワークが意図からプラン系列を生成 し，行動ネットと呼ばれる二段目のネットワークのプ ランユニットにプランを供給している。この行動ネッ トの出力として行動の系列が生成される。

バックプロパゲーションアルゴリズムを用いて，ま ず背景知識を予備訓練によって学習させ, 初心者と同 じように極めて遅い動きを示すモデルが得られる。更 に 1,600回の学習を行うと, 所要ステップ数が 7 ステ ップから 3 ステップヘと隇少した。プランユニットは 以前には，一時に一つのアクションしか表現できなか ったのに、いまや三つの行動からなる系列全体を表現 できるようになった。このネットワークでのチャンキ ングにより，逐次的な初心者から並列的なエキスパー トへの遷移をうまくモデル化している。

タイピングにおいて、キーストローク間の所要時間 は，頻度の高い場合のほうが低い場合よりも短いとい う実験結果がある。このモデル上でも同様な結果が統 計的に有意に得られている。

また，頻繁な行動が意図した行動を置き換えてしま うという獲得唄り (capture error) は人間によく見 られる詥りである。二つの系列が類似の部分系列を有 していると両者の状態層活性度が類似し, 類似入力に 対して類似出力というネットワークモデルの特性によ り，獲得器りを自然にモデル化できる。

頻度と類似度の二つの因子が獲得誤りの確率に影響 を与える。頻度に関しては，低頻度から高頻度への誤 
クがその逆よりも多い。また類似度に関しては，類似 度の高い系列間の誤りが類似度の低い系列間の誤りよ り多い。この獲得器りに関しても統計的に有意なモデ ル結果が得られている。

行動計画の制御への応用の場面では，次の上うな困 難がある。行動により環境がどうなったかがわかるだ けであり，望ましい行動を教える教師がいない。また 望ましい環境はゴールという形で部分的にしか与えら れない。ただ,人間はこのような状況下ても学習や行 動計画が可能である。

この問題に対して EAE (Environment-ActionEnvironment）ネットワークを提案し， $E \rightarrow A$ およ び $A \rightarrow E$ の双方向の写像を訓練パターンを与えて学 習させ，両者を交互に練返し用いることにより，上記 の困難を克服している(9)。

この EAE ネットワークては，時間経過まで含めて 一つのパターンとしているので，Eュニット数（空 間的メッシュ数メ時間的メッシュ数〉が大きくなり過 ぎるという問題点がある。また過剩自由度がある場合 には，逆写像が一対多となることも問題点と言えよ う。

\section{6. 行動の組織化}

行動の組織化の三つの基本的問題として, 自由度問 題, 逐次序列問題, 感覚モー夕学習 (sensorimotor learning) が Jordan によって取上げられている( ${ }^{(10)}$ 。

一般にシステムのもつ自由度が大きいほど, システ ムを制御するのが困難になる。またシステムのもつ自 由度がタスクを指定するに必要な自由度より大きい場 合, 非決定性が生ずる。従って, 自由度を減らすこと が重要である。

自由度を減らす第 1 の方法は階層性の利用であり， これにより暗黙の制約の導入，自由度相互作用の軽 减, 自由度の分割などが可能となる。第 2 の方法はフ イードバックの利用であり, 工学の場てよく用いられ ている。第 3 は評価関数の導入により, 複数の行動間 の選択基準を与えるものである。例として，所要時 間, 消費エネルギー量, 滑らかさなどがある。第 4 は 手足の内在的動特性の利用である。

感賞モー夕学習は感賞器とモータ制御との連合によ り，出力が出力目標に一致するように制御入力を決定 することであり，これに関しても以下のような様々な 方法がある。

（1）強化学習 (reinforcement learning) 強 化学習は可能な応答集合中の各要素の選択確率を学習 するものである。ただ制御の場合には、この選択確率
が入力に依存するように抬張する必要がある。強化学 習は外界からの教示がほとんどなくても学習が可能て ある。教示がある場合でももちろん利用可能ではある が，学習速度は外界からの教示を利用する場合に比へ 遅くなる。

（2）逆モデル法 フィードフォワードコントロ 一ラと対象システムをタンデムにつないだ場合, 前者 が後者の逆特性であれば望ましい制御が容易である。 この対象システムの逆モデルを求める方法は，以下の ように分類される。第 10 方法は，Widrow \& Hoff による最小自乗アルゴリズムを用いる連合的アプロー チてある。第 2 は，対象の構造知識を利用する非連合 的アプローチであるが，構造知識が得られないと使え ない。第 3 は，計算量を減らすために出力目標と制 入カとのテーブルを用いる方法であるが,このテーフ ルが大きくなり過ぎる危険性がある。第 4 は,テーブ ルとシステムの構造知識をともに利用する方法であ る。以上の四つの方法はいずれも出力系列をより望ま しい方向へと変更するメカニズムが入っていない。第 5 は、フィードバック中の誤差情報を利用して逆モテ ルの学習を行う川人らの方法である(12)。当初は顆も デルを用いて遅いフィードバック制御を行うが, 逆モ デルの学嫼が進むとこれを用いたより速いフィードフ オワード制御に置き変えられる。第 6 は, 出力誤差系 列が零になるように,フィードフォワード制御則を変 換する方法である(13)。その際，対象システムの逆モ デルが用いられる。この逆モデルが正確だと 1 回でフ イードフォード制御則が求まるが,一般には繰返し によってこれを求める必要がある。

（3）フォワードモデル法 まずフォワードモデ ル（対象システムのモデル）を学習し，次にコントロ ーラを学畾するというものである。この方法の利点 は,フォワードモデルの学習ができると, 出力系列を より望ましい方向へと変更できるようになる。また, フォワードモデルがあると結果の予測が可能となり， 過剩自由度問題をも解決するものである。なお,フォ ワードモデルが完全でなくても学習は可能である。

ただこのフォワードモデル自体は現在のところ動 的ではなく，静的で非線形な関係を表現するにとどま っている。一般の制御問題としてとらえるとこれを動 的なモデルに拉張することが必要であるが，この应镸 はそれほど困難てはないと考えられる。

教師付き学習 (supervised learning) の一般化とし て, 出力に対する不等号制約, don't care 条件, 線形 制約，非線形制約などの様々な構造的制約を平価の一 項目に変換する方法，およひ時間的制約を評価の一項 
目に変換する方法をJordan が示している(11)。後者の 時閏的制約は，過䣋自由度問題に対する解でもある。 すなるち，これを時間的制約ととらえ，滑らかさ評価 に変換することにより解決できるとしている。

\section{7.終りに}

本稿では動的システムの学習と制御について概観し た。ただ，時間を取入れたパターン認識 ${ }^{(14)}$, 自然言 語で語順からクラスの発見 ${ }^{(15)}$, コンテクストモデル やバッファモデルの学習能力の比較(4)(16)など, ダイナ ミクスに関する研究で, 紙面の都合上割愛したものも 多い。

コネクショニズムによる動的システムの学習と制㣵 の研究はまだ新しく，残された問題点も多い。また伝 統的な制御理論との対比もまた十分にはなされていな い。制御理論がまず対象のモデルを同定し，これに基 づいて制御則を求めるのに対し，コネクショニズムで はこの両者が分かれていないことが多い。この末分離 は，伝統的記号主義でプログラムとデータが分傩して いたのに対し，コネクショニスムムでこの両者が一つ のネットワーク中に混然一体となっている事情と類似 しており, 興昧哚い。今後この分野の一層の発展を期 待したい。

(平成元年 2 月 21 日受付)

$$
\text { 文献 }
$$

(1) D. E. Rumelhart, et al.: Parallel Distributed Processing, Vol. 1 \& Vol. 2 (1986) The MIT Press

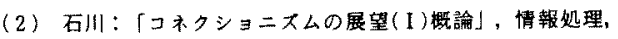
29, 666 (昭 63).

(3) 石II! 「コネクショニスムとシミュレーション」,シミコレ 一ション, 7, 83(昭63)

(4) 石川：「ダイナミッタコネクショニストモデル」, 电気学会 システム・制御研矣，SC-88-18，13 (1988)

(5) 石川! [コネクショニストアプローキによるインタフェース のニーザモデル」，人工知能学会誌揭截予定

(6) M. 1. Jordan: "Serial order: a parallel distributed proces sing approach", ICS Report 8604, UC San Diego (1986)

(7) D.E. Rumelhart \& D. A. Norman: "Simulating a skilled typist : A study of skilled cognitive-motor performance". Cognitive Science, 6, 1(1982)

(8) Y. Miyata: "Organization of action seguences in motor learning: A connectionist approach", Cognitive Science Society Conference (1987)

(9) Y. Miyata: "An unsupervised PDP learning model for action planning". The Tenth Annual Conference of the Cognitive Science Society, p. 223 (1988)

(10) M. I. Jordan: "Action", COINS Technical Report 88-26, University of Massachusetts at Amherst (1988)

(11) M. I. Jordan: "Supervised learning and systems with excess degrees of freedom", COINS Technical Report 8827, University of Massachusetts at Amherst (1988)

(12) M. Kawato, K. Furukawa, \& R. Suzuki : "A hierarchical neural-network model for control and learning of voluntary movement", Biological Cybernetics, 57, 169 (1987)

(13) C. G. Atkeson \& J. McIntyre: "Robot trajectory learning through practice". IEEE Conference on Robotics and Automation, p. 1737 (1986)

(14) M. C. Mozer: "A focused back-propagation algrithm for temporal pattern recognition", Technical Report CRBTR. 88-3, Univ. of Toronto (1988)

(15) J. L. Elman": Finding structure in time", CRL Technical Report 8801, UC San Diego (1988)

(16) K. Kukich: "Back-propagation topologies for sequence generation", IEEE International Conference on Neural Networks, 1301/308, San Diego, CA, (1988) 